\title{
ANALISIS PENGEMASAN PRODUK BERBASIS TEKNOLOGI INFORMASI DI UPT PERPUSTAKAAN UNIVERSITAS RIAU \\ Yuhelmi \\ yuhelmi@unilak.ac.id
}

\begin{abstract}
This study aims to analyze the packaging of information technology-based products used UPT Library University of Riau and to find out the evaluation results of users and stakeholders in the packaging of information technology-based products that have been run in UPT Library University of Riau. The type of research used is descriptive evaluative type, that is to an already running program (Ex Post Program Evaluation) to find out whether the information technologybased products that have been served UPT Library University of Riau in accordance with the wishes of the user. Respondents in this study are 4 staff involved in the process of packaging of information technology-based products as well as 3 people leadership as a booster of the results of this study and some users as an evaluation of products that have been laying. Evaluation activities are carried out in a participatory manner, involving users and stakeholders, as this process is a lesson to reflect on what has been done. It must be aware of its strengths and weaknesses, which then think and plan what needs to be done for further improvement. Based on the results of the analysis of three information technology-based products that have been dilayankan still need serious development so that the needs of users or users can be met. Then stakeholder perceptions of information technology-based services is good but still need revamping in terms of security, where ever the occurrence that the website they are hacked by someone who is not responsible so that thousands of journals disappear and can not be returned.
\end{abstract}

Keywords: Product Packaging Analysis, Information Technology, UPT Library University of Riau

\begin{abstract}
Abstrak
Penelitian ini bertujuan menganalisis pengemasan produk berbasis teknologi informasi yang digunakan UPT Perpustakaan Universitas Riau dan untuk mengetahui hasil evaluasi dari pengguna dan stakeholder dalam pengemasan produk berbasis teknologi informasi yang telah dijalankan di UPT Perpustakaan Universitas Riau. Jenis penelitian yang digunakan adalah jenis deskriptif evaluatif, yaitu terhadap suatu program yang sudah berjalan (Ex Post Program Evaluation) untuk mengetahui apakah produkberbasis teknologi informasi yang
\end{abstract}


sudah dilayankan UPT Perpustakaan Universitas Riau sesuai dengan keinginan pengguna. Responden dalam penelitian ini adalah 4 staf yang terlibat dalam proses pengemasan produk berbasis teknologi informasi serta 3 orang pimpinan sebagai penguat hasil penelitian ini serta beberapa pengguna sebagai evaluasi tentang produk yang sudah layankan. Aktivitas evaluasi dilakukan secara partisipatif, dengan melibatkan pengguna dan stakeholder, karena proses ini merupakan pembelajaran untuk melakukan refleksi mengenai apa yang telah dilakukan. Harus disadari kekuatan dan kelemahannya, yang selanjutnya berpikir dan merencanakan apa yang harus dilakukan untuk perbaikan selanjutnya. Berdasarkan hasil analisis peneliti tiga produk berbasis teknologi Informasi yang sudah dilayankan tersebut masih perlu pengembangan yang serius agar kebutuhan pengguna atau user dapat dipenuhi.Kemudian Persepsi stakeholder terhadap layanan berbasis teknologi informasi sudah baik namun masih perlu pembenahan dari segi keamanan, dimana pernah kejadian bahwa situs web mereka diretas oleh orang yang tidak bertanggng jawab sehingga ribuan jurnal hilang dan tidak bisa dikembalikan.

Kata kunci: Analisis Pengemasan Produk, Teknologi Informasi, UPT Perpustakaan Universitas Riau

\section{PENDAHULUAN}

Agar tujuan pendidikan tinggi tercapai maka keberadaan suatu perguruan tinggi harus ditunjang dengan adanya perpustakaan. Di sini kedudukan perpustakaan adalah penting sebagai pintu gerbang informasi untuk menunjang proses belajar mengajar, penelitian, dan pengabdian masyarakat (Tri Dharma Perguruan Tinggi). Menurut Lasa Hs, perpustakaan merupakan sistem informasi yang didalamnya terdapat aktivitas pengumpulan, pengolahan, pengawetan, pelestarian dan penyajian, serta diseminasi informasi. Informasi meliputi produk intelektual dan artistik manusia. ${ }^{1}$ Saat ini perkembangan ilmu pengetahuan termasuk ilmu perpustakaan dan informasi, secara berangsur-angsur menghendaki adanya perubahan dalam pengelolaan perpustakaan. Perpustakaan tidak hanya sebagai lembaga yang mengumpul, mengelola, menyimpan, dan melestarikan bahan pustaka, tetapi lebih mengutamakan pada penyebaran informasi (dissemination of information).

Menyadari pentingnya perkembangan teknologi informasi dan komunikasi (information and communication technology) membawa perubahan dalam dunia perpustakaan, maka perpustakaan memerlukan kerjasama dengan beberapa stakeholders.

UPT perpustakaan Universitas Riau telah manggunakan otomasi perpustakaan beberapa tahun terakhir dengan program Slims secara terintegrasi. Artinya dari proses pengolahan, pelayanan, dan penelusuran dapat digunakan secara bersamaan dan saling kait mengkait. Namun demikian masih ada kendala yang dihadapi, yaitu belum adanya networking

\footnotetext{
${ }^{1}$ Lasa Hs. Manajemen Perpustakaan. Yogyakarta : Gama Media, 2005. hal. 48
} 
dengan perpustakaan fakultas di lingkungan Universitas Riau. Mencermati betapa pentingnya perpustakaan dalam memberikan layanandengan cepat dan tepat, selayaknya perlu ditumbuh kembangkan melalui berbagai program dan kegiatan yang realistis sehingga dapat mencapai sasaran yang dikehendaki.Untuk itu UPT Perpustakaan Universitas Riau bekerjasama dengan pihak UPT Puskom Universitas Riau membangun database baru yang berbasis web. Dengan harapan ke depan semua jenis koleksi yang ada di UPT Perpustakaan Universitas Riau dan perpustakaan fakultas di lingkungan Universitas Riau dapat terakses melalui internet dengan informasi yang realtime (pada saat itu juga), sehingga pengguna akan mendapatkan kepuasan layanan yang beragam secara relevan, akurat, dan cepat. Jenis layanan informasi yang di tujukan ke khalayak adalah produk-produk yang dihasilkan dan diolah oleh UPT Perpustakaan Universitas Riau, baik produk dalam bentuk tercetak maupun elektronik. Untuk produk informasi tercetak salah satu sumbernya didapatkan melalui kegiatan exhibitions atau pameran buku. Untuk kemudian produk akan diproses dan dilayankan secara online katalog melalui media intranet dan internet. Media online katalog ini dikembangkan bekerjasama dengan pihak UPT Puskom Universitas Riau. Sedangkan produk dalam bentuk elektronik seperti e-journal, UPT Perpustakaan Universitas Riau bekerjasama dengan pihak lain. Kerjasama pihak perpustakaan dengan stakeholder ini meliputi, yaitu pihak rektorat sebagai pemegang kebijakan, sivitas akademika sebagai pengguna, UPT Puskom Universitas Riau sebagai mitra kerja dalam pengembangan layanan berbasis teknologi informasi, dan beberapa penerbit/distributor sebagai mitra kerja dalam pengadaan dan pengembangan koleksi. Dari gambaran di atas menunjukkan bahwa keberadaan produk informasi dalam bentuk elektronik pada jasa pelayanan informasi di perpustakaan sangat diperlukan.

Salah satu upaya yang dilakukan UPT Perpustakaan Universitas Riau adalah melakukan pengemasan produk berbasis teknologi informasi. Namun sebaik apapun produk dan layanan perpustakaan, tidak akan banyak gunanya bila tidak banyak orang yang tahu dan menggunakannya. Karena itu diperlukan sebuah proses yang bernama pemasaran (marketing). Dalam memasarkan produk dan jasa layanan perpustakaan, maka perlu suatu strategi komunikasi pemasaran, yaitu dengan bauran pemasaran (marketing mix) yang terdiri dari product, price, place dan promotion. Atau bisa dikatakan bahwa promosi merupakan elemen penting dari bauran pemasaran. Secara umum promosi dilakukan melalui beberapa elemen (promotion mix), salah satunya adalah melalui pengemasan produk. $^{2}$

Promosi perpustakaan perlu dilakukan supaya seluruh aktivitas yang berhubungan dengan jasa perpustakaan dapat diketahui dan dipahami oleh pengguna. Promosi merupakan salah satu komponen pemasaran, dengan mempromosikan kelembagaan, koleksi, sistem dan jenis pelayanan, maka terjadilah proses pendekatan informasi kepada pengguna.

\footnotetext{
${ }^{2}$ PR Smith. Marketing Communications: An Integrated Approach. London: Kogan Page, 1998. P. 7
} 
Agar promosi efektif maka diperlukan sebuah perencanaan, pengorganisaian, dan pelaksanaan yang baik, selanjutnya dilakukan evaluasi pada periode waktu tertentu. Sehingga sasaran yang ingin dicapai dapat terlaksana tepat waktu, tepat cara, dan tepat sasaran. Berdasarkan kajian model pengemasan produk berbasis teknologi informasi tersebut, akan diketahui kekuatan, kelemaham, kesempatan, dan ancaman. Di sini peneliti tertarik untuk melakukan kajian pengemasan produk berbasis teknologi informasi yang dilakukan oleh UPT Perpustakaan Universitas Riau dikarenakan melihat fenomena pergeseran orientasi kebutuhan pengguna akan informasi berbasis teknologi informasi seiring dengan perkembangan teknologi dan ilmu pengetahuan yang begitu cepat.Untuk itu perlu dilakukan inovasi berbasis kebutuhan pemakai.

\section{TINJAUAN PUSTAKA}

\subsection{Pemasaran}

Pemasaran berhubungan dengan mengidentifikasi dan memenuhi kebutuhan manusia dan masyarakat. Salah satu dari definisi pemasaran terpendek adalah "memenuhi kebutuhan secara menguntungkan". Suatu proses sosial dan manajerial yang membuat individu dan kelompok memperoleh apa yang mereka butuhkan dan inginkan, lewat penciptaan dan pertukaran segala sesuatu yang bernilai dengan orang atau kelompok lain.

American Marketing Association (AMA) merilis definisi terbaru mengenai pemasaran pada tahun 2004 yang menyebutkan :

Pemasaran adalah fungsi organisasi dan serangkaian proses menciptakan, mengkomunikasikan, dan menyampaikan nilai bagi parapelanggan sedemikian rupa sehingga memberikan manfaat bagi organisasi dan para stakeholders-nya. ${ }^{3}$

Selain itu perlu suatu komunikasi dengan konsumen. Hal inilah yang melatar belakangi perlu suatu aplikasi komunikasi dalam pemasaran. Komunikasi pemasaran memegang peranan yang sangat penting bagi pemasar. Tanpa komunikasi, konsumen maupun masyarakat secara keseluruhan tidak akan mengetahui keberadaan produk di pasar.. Dalam menjalankan program komunikasi pemasaran, diperlukan suatu perencanaan secara matang.

Dalam pemasaran sumber berarti pihak yang mengirim pesan pemasaran kepada konsumen. Proses selanjutnya yaitu pemasar menentukan bagaimana pesan itu disusun agar bisa dipahami dan direspons secara positif oleh penerima dalam hal ini konsumen. Dalam proses tersebut ditentukan pula jenis komunikasi apa yang akan digunakan. Apakah pesan akan disampaikan melalui iklan, personal selling, promosi,

\footnotetext{
${ }^{3}$ Fandy Tjiptono. Pemasaran Strategik. Yogyakarta: Andi, 2008. hal. 5
} 
hubungan masyarakat atau dengan direct marketing. Keseluruhan proses dari perancangan pesan sampai penentuan jenis promosi disebut proses encoding

Proses selanjutnya yaitu menyampaikan pesan melalui media (cetak/elektronik). Proses penyampaian pesan melaui media ini disebut proses transmisi. Pesan yang disampaikan melalui media akan ditangkap oleh penerima dengan respon positif atau negatif. Respon positif identik dengan terjadinya keserasian antara harapan pengirim pesan dengan tanggapan penerima pesan. Proses memberikan respon dan menginterpretasikan pesan yang diterima disebut sebagai proses decoding.

Menurut Tjiptono, tujuan utama dari promosi adalah menginformasikan, mempengaruhi, dan membujuk, serta mengingatkan pelanggan sasaran tentang perusahaan dan bauran pemasarannya. ${ }^{4}$ Secara singkat promosi berkaitan dengan upaya untuk mengarahkan seseorang agar dapat mengenal produk perusahaan, lalu memahaminya, berubah sikap, menyukai, yakin, kemudian akhirnya membeli dan selalu ingat akan produk tersebut. Promosi terutama diarahkan pada calon pembeli yang sudah dikenal atau diketahui secara pribadi.

\subsection{Promosi Perpustakaan}

Promosi perpustakaan adalah upaya mengenalkan seluruh aktivitas yang ada di perpustakaan agar diketahui oleh khalayak umum.

Pada dasarnya segala daya upaya yang dilakukan melalui promosi dalam dunia perpustakaan memiliki sasaran untuk meningkatnya jumlah pengunjung perpustakaan, meningkatnya buku yang dipinjam serta meningkatnya pemanfaatan koleksi maupun sumber daya yang ada di perpustakaan(Yuhelmi, Y., \& Rosman, 2015)

Salah satu faktor penting terhadap keberhasilan pemasaran jasa perpustakaan adalah promosi. Sebagai dasar pemikiran untuk melakukan kegiatan promosi adalah komunikasi, karena dengan adanya komunikasi diharapkan terjadi interaksi antara produsen dengan konsumen. Komunikasi akan berjalan dengan baik apabila pesan yang diterima sama dengan pesan yang dikirim. Karena itu, produsen suatu produk atau jasa harus melintasi jalur tersebut untuk mengkomunikasikan produk ke pengguna atau calon konsumen

Di dalam proses pemilihan alat-alat promosi yang digunakan, tergantung pada siapa yang akan dijangkau, apa yang akan ditawarkan,apa yang akan dikomunikasikan, dan bagaimana audien menanggapai pesan. Juga tergantung pada kekuatan (Strenghts) dan kelemahan (Weaknesses) internal organisasi disamping peluang (Opportunities) dan tantangan (Threats) eksternal organisasi. Sebenarnya secara sadar ataupun tidak pustakawan sudah banyak melakukan promosi, akan tetapi kegiatan tersebut tidak/belum terencana sehingga tidak/belum mencapai tujuan maupun sasaran perpustakaan. Menurut pengamatan penulis ada

\footnotetext{
${ }^{4}$ Fandy Tjiptono,Strategi Pemasaran Yogyakarta : andi Offset,1995. Hal.200
} 
beberapa alat promosi yang digunakan oleh UPT Perpustakaan Universitas Riau, yaitu : brosur, exhibition (pameran), orientasi mahasiswa baru, seminar perpustakaan, pelatihan otomasi perpustakaan, packaging atau pengemasan (CD interaktif, digital library, e-journal, katalog online). Namun dalam penelitian ini peneliti membatasi kajian melalui media promosi dalam bentuk packaging (digital library, e-journal, dan katalog online).

\subsection{Pengemasan Produk Perpustakaan}

Pengemasan informasi adalah kegiatan yang dimulai dari menyeleksi berbagai informasi dari sumber yang berbeda, mendata informasi yang relevan, menganalisis, mensintesa, dan menyajikan informasi yang sesuai dengan kebutuhan pemakai. Informasi yang dikemas kembali memberi kemudahan dalam penyebaran informasi dan temu kembali informasi. ${ }^{5}$

Jadi pengemasan merupakan sebuah usaha mengemas kembali dalam bentuk yang lebih baik dan menarik. Betapapun lengkapnya suatu koleksi informasi, tidak akan memberikan manfaat bila tidak dikemas kembali dan dikomunikasikan ke pengguna aktual maupun potensial. Harus diakui bahwa kualitas barang ataupun jasa adalah besar sekali pengaruhnya terhadap kelancaran penjualan, dalam hal ini masalah kemasan tidak boleh dilupakan. Dengan demikian kemasan yang menarik akan mempercepat kelancaran penjualan barang. Charles A. Bresin petugas dari Packaging magazine Amerika mengatakan "Bahwa kemasan tidak hanya merupakan pelayanan tapi juga sebagai salesman dan pembawa kepercayaan."6

\subsubsection{Digital Library}

Berdasarkan Wikipedia Indonesia, ensiklopedia bebas berbahasa Indonesia, menyebutkan :

Perpustakaan digital (Inggris: digital library atau electronic library atau virtual library) adalah perpustakaan yang mempunyai koleksi buku sebagian besar dalam bentuk format digital dan yang bisa diakses dengan komputer. Jenis perpustakaan ini berbeda dengan jenis perpustakaan konvensional yang berupa kumpulan buku tercetak, film mikro (microform dan microfiche), ataupun kumpulan kaset audio, video, dll. Isi dari perpustakaan digital berada dalam suatu komputer server yang bisa ditempatkan secara lokal, maupun di lokasi yang jauh, namun dapat diakses dengan cepat dan mudah lewat jaringan komputer." 7

\footnotetext{
${ }^{5}$ Joko Santoso. "Kemas Ulang Informasi Elektronis Sebagai Langkah Inovatif Layanan Perpustakaan :Teknologi Informasi dan Pengaruhnya Pada Pengemasan Informasi." 25 Maret $2008<w w w . p n r i . g o . i d>$

${ }^{6}$ Buchari Alma. Manajemen Pemasaran dan Pemasaran Jasa. Bandung: Alfabeta, 1998. hal. 111

7 "Perpustakaan Digital" 20 juni 2008 <http://encyclopaedia.thefreedictionary.com/digital+library>
} 
Singkatnya koleksi digital sebenarnya dapat dipahami sebagai koleksi informasi dalam bentuk elektronik atau digital yang mungkin terdapat juga dalam koleksi cetak, yang dapat diakses secara luas menggunakan media komputer dan sejenisnya. Koleksi digital disini dapat bermacam-macam, dapat berupa buku elektronik, jurnal elektronik, database online, statistic elektronik, dan lain sebagainya.

\subsubsection{E-Journal}

Menurut Glossary yang dikeluarkan oleh African Digital Library, yang dimaksud dengan e-journal adalah :

An article or complete journal available fully electronically via a web-site on the Internet. It could be available free or as part of a paid for service. This trend is older and more established than the trend of providing e-book content via the Internet. ${ }^{8}$

Artikel-artikel untuk jurnal ilmiah merupakan pengetahuan primer, berbeda dengan buku pelajaran yang merupakan pengetahuan sekunder. Pengetahuan primer baru akan ada apabila ada penelitian baru, jadi suatu penerbit tidak dapat begitu saja menerbitkan jurnal ilmiah dan mencari artikel untuk jurnalnya. Apabila tidak ada yang meneliti maka tidak ada jurnal yang perlu diterbitkan.

Saat ini banyak perpustakaan perguruan tinggi berlangganan database online yang berisi berbagai macam jurnal elektronik maupun artikel elektronik. Melalui database online ini perpustakaan mampu menyediakan koleksi digital yang dapat diakses oleh pengguna perpustakaan dalam wilayah area tertentu. Ebscohost dan Proquest adalah dua contoh database

Untuk membangun sistem perpustakaan digital, ada banyak aplikasi yang bisa digunakan, baik yang komersial maupun yang Open Source.

\subsubsection{Katalog Online}

Tujuan utama katalog terkomputerisasi adalah membuat suatu sistem pengkatalogan yang sesuai dengan pemanfaatannya.. Sumbersumber pembuatan katalog online (terkomputerisasi) didapatkan dari:

a. Katalog manual local yang berbentuk lembaran atau kartu tercetak. File yang telah dibuat oleh Kataloger, baik yang telah berformat MARC maupun belum

b. Penggabungan (integrasi) file database katalog antar perpustakaan;

c. Membeli katalog komersial berformat MARC.

\section{TUJUAN DAN MANFAAT PENELITIAN}

\subsection{Tujuan Penelitian}

Tuajuan Penelittan ini :

\footnotetext{
8 “African Digital Library Glossary”. (2002).20 Juni 2008 <http://www.africandl.org.za/glossary.htm>
} 
1. Untuk menganalisis produk berbasis teknologi informasi yang digunakan UPT Perpustakaan Universitas Riau.

2. Peran dan persepsi stakeholders dalam pengelolaan pengemasan produk.

\subsection{Manfaat Penelitian}

Manfaat dari penelitian ini adalah

1. Sivitas Akademika UR dan juga umum menjadi paham dan mengetahui jenis layanan yang dimiliki oleh UPT UR dengan layanan berbasis Teknologi Informasi sehingga semua sivitas dapat memanfaatkan produk yang sudah dilayankan UPT erpustakaan dengan baik.

2. Megetahui persepsi stakeholder terhadap pengemasan produk berbasis Teknologi Informasi yang sudah dilayankan.

\section{METODE PENELITIAN}

\subsection{Tempat dan Waktu}

Penelitian ini dilaksanakan selama 8 (delapan) bulan, dimulai pada bulan Maret sampai dengan bulan September 2017 yang meliputi kegiatan persiapan, penelitian lapangan, pengolahan data dan penyusunan laporan Adapun lokasi penelitian dilakukan di Universitas Riau, Jl. HR Subrantas Panam.

\subsection{Pengumpulan data}

Data yang dipergunakan dalam penelitian ini adalah data primer dan data sekunder. Untuk mengumpulkan data primer maka dilakukan obervasi langsung di lapangan yang meliputi pengamatan langsung dilapangan dengan melakukan wawancara langsung dengan stakeholder dan pengguna.

Data Primer digunakan untuk mengetahui kondisi pengemasan yang dilakukan diperoleh melalui kegiatan wawancara, baik wawancara dengan panduan kuesioner (daftar isian) maupun wawancara mendalam (indepth interview). Kepada Stakeholder, sivitas dan para pengguna yang sering memanfaatkan perpustakaan dalam pemenuhan informasi yang mereka butuhkan..

Selanjutnya data sekunder diperoleh dengan metode studi pustaka (desk study) yang diperoleh dari UPT Perpustakaan Universitas Riau (UR), Puskom UR, UPT Universitas Lancang Kuning dan dari berbagai penelitian, dokumendokumen lainnya dengan tema yang sama untuk kemudian dianalisis.

\subsection{Prosedur penelitian}

Pengemasan informasi adalah kegiatan yang dimulai dari menyeleksi berbagai informasi dari sumber yang berbeda, mendata informasiyangrelevan, menganalisis, mensintesa, dan menyajikan informasi yang sesuai dengan kebutuhan pemakai. Informasi yang dikemas kembali memberi kemudahan dalam penyebaran informasi dan temu kembali informasi. Aktivitas evaluasi dilakukan secara partisipatif, dengan melibatkan stakeholder dan pengguna, karena proses ini merupakan pembelajaran 
untuk melakukan refleksi mengenai apa yang telah dilakukan, harus disadari kekuatan dan kelemahannya, yang selanjutnya berpikir dan merencanakan apa yang harus dilakukan untuk perbaikan selanjutnya

\subsection{Analisis Data}

Analisis merupakan proses pencarian dan perencanaan secara sistematis semua data dan bahan yang telah terkumpul agar peneliti mengerti benar makna yang telah dikemukakannya dan dapat menyajikannya kepada orang lain secara jelas. ${ }^{9}$ Analisis yang digunakan dalam penelitian ini adalah dengan menggunakan pendekatan deskriptif evaluatif tentang model pengemasan produk berbasis teknologi informasi di UPT Perpustakaan UR.

Dalam proses pengumpulan data penulis menggunakan teknik wawancara, dokumen, dan observasi langsung ke lokasi penelitian. Data yang dikumpulkan dalam penelitian ini berupa deskripsi data yang telah disusun secara teratur dengan menggunakan pola penelitian induktif yang diolah secara interaktif. Artinya jalinan data antara yang satu dengan yang lain senantiasa dipertahankan baik pada pra pelaksanaan, pelaksanaan maupun pada waktu penyusunan hasil penelitian. Setelah data terkumpul dilakukan proses seleksi data, kemudian data tersebut disajikan secara sistematis sehingga akan lebih mudah dipahami. Dari penyajian data yang telah diolah tersebut diinterpretasikan dan ditarik suatu kesimpulan.

Teknik analisis yang digunakan dalam penelitian ini melalui tiga komponen:

1. Reduksi Data

2. Sajian Data

3. Penarikan Simpulan dan Verifikasi

Ketiga komponen tersebut membentuk interaksi dengan proses pengumpulan data sebagai sebuah siklus. Proses tersebut bisa digambarkan sebagai berikut:

\section{HASIL DAN PEMBBAHASAN}

\subsection{Hasil}

Perpustakaan Universiatas Riau didirikan pada tahun 1962 bersamaan dengan berdirinya Universitas Riau yang masih di bawah naungan Yayasan Universitas Riau dan hanya menempati ruang seluas 100 meter persegi. Pada tahun 1980 Perpustakaan Universitas Riau hanya memiliki gedung seluas 500 meter persegi yang terletak di lokasi kampus lama jalan Pattimura No. 9 Pekanbaru. Sejak tahun 1992 Perpustakaan Universitas Riau dipindahkan ke kampus baru yakni Kampus Bina Widya Panam Jalan HR Soebrantas KM 12,5 Simpang Baru, Pekanbaru sejalan dengan dipindahkannya kantor Rektorat dan beberapa fakultas.

${ }^{9}$ Lexy J Moleong. Metode Penelitian Kualitatif. Bandung: Remaja Karya., 1991. Hal. 112 
Perpustakan UR memiliki gedung sebanyak empat unit masing-masing terdiri dari dua lantai. Dari empat unit yang ada perpustakaan hanya menempati dua gedung dengan luas keseluruhannya 4.000 meter persegi dengan kapasitas 250 tempat duduk, dibangun di atas lahan seluas $2 \mathrm{Ha}$.

Perpustakaan saat ini melayani lebih dari 27.500 mahasiswa, 1.400 dosen dan 654 karyawan. Perpustakaan Universitas Riau menyimpan lebih dari 132.000 judul atau 365.000 eksemplar koleksi bahan pustaka, dengan pertambahan setiap tahun sekitar 8.500 eksemplar. Selain itu perpustakaan Universitas Riau memiliki koleksi elektronik yang terdiri dari jurnal dan bahan-bahan koleksi "local content". Jumlah e-journal yang dilanggan lebih dari 5.000 judul dalam berbagai disiplin ilmu yang diperlukan terutama oleh sivitas akademika UR. Kedua jenis koleksi elektronik jurnal tersebut dapat diakses melalui jaringan www: lib.unri.ac.id dan www:ur-lib.com.

Perpustakaan UR sudah dua tahun ini menggunakan sistem otomasi perpustakaan dengan menggunakan program SliMS dan untuk pelayanannya sudah dikembangkan komplemennya dari pengembangan program SliMS Cendana, aplikasi pelayanan mandiri yang telah diterapkan untuk transaksi peminjaman, perpanjangan dan pengembalian buku dalam upaya untuk meningkatkan pelayanan. Penerapan aplikasi Pelayanan Mandiri ini sejak tanggal 30 Agustus 2013.

Perpustakaan UR mendapat nilai terbaik dalam akreditasi perpustakaan Tahun 2013, yaitu Kategori "A" . Hasil penilaian akreditasi Perpustakaan UR oleh Tim Asesor Perpustakaan Nasional RI dari 17 September hingga 18 Desember 2013 tertuang dalam Sertifikat Akreditasi Perpustakaan Perpustakaan Nasional RI Nomor 19/1/ee/XII.2013

\subsection{Pembahasan}

\section{A. Pemetaan Khalayak UPT Perpustakaan Universitas Riau}

\section{Segmentasi Perpustakaan}

Dalam pendekatan pemasaran ada beberapa hal yang menjadi pertanyaan utama antara lain: Siapa pemakai utama atau konsumen dari perusahaan? Apa yang pemakai inginkan? Apa yang dapat dilakukan perusahaan agar keinginan pemakai terpenuhi? Dan dengan cara apa perusahaan dapat memenuhi kebutuhan pemakai? Praktik di dunia pemasaran dan jasa tersebut juga terjadi di perpustakaan. Pembeli atau konsumen di perpustakaan disebut pengunjung atau pengguna (user). Perpustakaan harus jeli melihat pasar dan menentukan segmentasi penggunanya. Segmentasi pasar adalah proses pemisahan pasar total menjadi kelompok-kelompok pasar dengan kebutuhan yang sama. Pasar segmen adalah individu atau organisasi dengan ciri serupa sehingga kebutuhanyapun serupa. Di perpustakaan perguruan tinggi, segmen terdiri dari dua identifikasi, yaitu penguna aktual dan pengguna potensial. Sivitas akademika perguruan tinggi (dosen, karyawan, dan mahasiswa), alumni, mahasiswa/dosen di luar PT tersebut, merupakan segmen aktual yang harus dilayani. Sedangkan segmen potensial adalah sekelompok orang atau organisasi lain yang mungkin akan menggunakan produk atau jasa kita di masa yang akan datang. Di mungkinkan pelajar-pelajar di sekitar Pekanbaru, masyarakat umum (seperti warga sekitar), organisasi politik di Pekanbaru, atau berbagai yayasan pendidikan lainnya akan 
memanfaatkan jasa layanan produk berbasis teknologi informasi. Segmentasi pasar di UPT Perpustakaan UR adalah sebagai berikut :

1. Dosen seluruh fakultas di lingkungan UR

2. Mahasiswa S3, S2, S1, maupun DIII seluruh fakultas di lingkungan UR

3. Karyawan baik administrasi maupun fungsional di lingkungan UR

4. Pelajar, mahasiswa, dan dosen dari luar UR

5. Masyarakat umum

Adapun segmentasi Pengemasan Produk Berbasis IT adalah sebagai berikut :

Tabel 4. Segmentasi Pengemasan Produk Berbasis TI

\begin{tabular}{|l|l|}
\hline \multicolumn{1}{|c|}{ Jenis Pengemasan } & \multicolumn{1}{c|}{ Segmentasi } \\
\hline § Digital library & Sivitas akademika UR dan Umum \\
§ E -Journal & Sivitas akademika UR \\
$\S$ Katalog Online & Sivitas akademika UR dan Umum \\
\hline
\end{tabular}

Sumber : olah data peneliti, 2017

\section{Targeting Perpustakaan}

UPT Perpustakaan sebagai unit perpustakaan universitas dalam hal ini targetnya sudah jelas, yaitu seluruh sivitas akademika UR. Adapun targeting sivitas akademika meliputi :

1. Dosen seluruh fakultas di lingkungan UR

2. Mahasiswa S3, S2, S1, maupun DIII seluruh fakultas di lingkungan UR

3. Karyawan baik administrasi maupun fungsional di lingkungan UR

Jumlah pengguna dapat dapat dilihat sebagai berikut:

Tabel 5 Jumlah pengguna Perpustakaan s/d 1 Agustus 2017

\begin{tabular}{|l|r|r|l|}
\hline \multicolumn{1}{|c|}{ Status } & \multicolumn{1}{c|}{ Jumlah } & $\begin{array}{c}\text { Juml Terdaftar sbg anggt } \\
\text { Perp }\end{array}$ & $\%$ \\
\hline Mahasiswa & 27.500 & 8.460 & $31 \%$ \\
\hline Dosen & 1.400 & 5 & $0.4 \%$ \\
\hline Karyawan & 654 & 23 & $4 \%$ \\
\hline Jumlah & 29.554 & 8.488 & $29 \%$ \\
\hline
\end{tabular}

Sumber : olah data peneliti, 2017

Tabel 6. Jumlah Pengguna Jurnal Elektronik UPT Perpustakaan UR Th. 2017

\begin{tabular}{|l|c|}
\hline \multicolumn{1}{|c|}{ Bulan } & Penelusuran/Bulan... \\
\hline & Tahun 2017 \\
\hline Januari & 102 \\
\hline Februari & 92 \\
\hline Maret & 425 \\
\hline April & 398 \\
\hline
\end{tabular}




\begin{tabular}{|l|c|}
\hline Mei & 398 \\
\hline Juni & 234 \\
\hline Juli & 166 \\
\hline Jumlah & 1815 \\
\hline
\end{tabular}

Sumber : Bag. Pelayanan Internet, 2017

Berdasarkan data di atas, dapat dikatakan bahwa UPT harus lebih giat lagi mempromosikan keberadaan produk-produk berbasis teknologi informasi yang dimiliki UPT UR sebab masih sedikit yang terdafdar sebagai anggota dibanding dengan jumlah seluruh sivitas akademika yakni hanya 29\% maka UPT Perpustakaan UR perlu mengupayakan agar produk berbasis teknologi informasi yang tersedia termanfaatkan secara maksimal ke pengguna, terutama sivitas akademika. Dan yang memanfaatkan ejournal tahun 2017 sampai Juli berjumlah 1815 dari 8488 anggota perpustakaan sivitas akademika jika dipresentasekan hanya $21 \%$ yang memanfaatkan ejournal. Kemudian dosen yang menjadi anggota perpustakaan hanya 5 orang dari 1400 dosen yang ada.

Selain itu perpustakaan juga menerapkan pricing yang murah dalam pembuatan kartu anggota perpustakaan. Denda keterlambatan pengembalian buku juga lebih murah dibandingkan dengan denda ketelambatan buku di perpustakaan fakultas maupun universitas lain.

\section{B. Analisa Pengemasan Produk Berbasis Teknologi Informasi}

Pengemasan informasi melalui media internet, tentunya harus didukung dengan adanya infrastruktur informasi yang memadai. Untuk diseminasi informasi paling utama yang dibutuhkan adalah pulsa/bandwidh internet. Saat ini apabila dihitung rata-rata per mahasiswa mendapatkan $0,7 \mathrm{kbbs}$. Artinya kalau mahasiswa sudah mendapatkan aliran pulsa 0,7 kbbs sudah selayaknya mendapatkan aliran informasi yang berharga. Target akhir tahun 2008 minimal bandwidth per mahasiswa menjadi $0,76 \mathrm{kbbs}$. Jadi, ternyata infrastruktur memegang peranan penting dalam diseminasi/penyebaran informasi. Bandwidh internet menjadi pegangan dalam diseminasi/penyebaran informasi di seluruh dunia (wawancara dengan kepala UPT Puskom, 26 April 2017) Peran packaging di era informasi saat ini sangat penting dalam membangun image perpustakaan. Seperti yang diungkap oleh Kepala UPT Perpustakaan UR:

Di era elektronik, informasi begitu banyak. Tanpa berubah dari yang sifatnya manual ke komputer, perpustakaandianggap ketinggalan. Perpustakaan yang tidak masuk kesana pasti perpustakaan yang tertinggal. Hal inisangat penting, tidak hanya menjaga image, bahwa kita tidak tertinggal. Tapi banyak manfaat yang dapat diperoleh bila mengelektronikkan semua yang kita miliki, dibandingkan tetap bertahan menggunakan manual. (wawancara, 12 April 2017).

Digital library, e-journal, dan katalog online dikemas melalui situs web. Situs web adalah sebuah server yang menyajikan berbagai informasi dalam bentuk hypertext (html file) dan mempunyai URL (alamat situs) tertentu sehingga dapat diakses oleh pemakai internet dari manapun. Situs web UPT Perpustakaan UR dapat diakses pada alamat http://digilib.unri.ac.id. Situs ini menyediakan aplikasiaplikasi berupa layanan informasi berbasis web yang terdiri dari: (1) Katalog online menggunakan Slim Akasia, dimana pengguna bisa melihat koleksi buku apa saja yang dimiliki oleh UPT Perpustakaan UR ataupun koleksi yang dimiliki oleh perpustakaan-perpustakaan fakultas di lingkungan UR. (2) E-Journal, 
menampilkan 12000 judul jurnal dengan berbagai disiplin ilmu pengetahuan. Tampilan dalam bentuk full text (tidak semuanya), dan setiap pengguna dalam akses jurnal tersebut free atau tidak dipungut biaya, dengan syarat pengguna adalah sivitas akademika UR. (3) Digital Library, menampilkan dokumen hasil karya mahasiswa, dosen, dan karyawan UR. Untuk karya mahasiswa meliputi tugas akhir, skripsi, dan tesis serta disertasi.

Fungsi Internet di sini sebagai supporting system dalam penelusuran informasi pada digital library, e-journal, dan katalog online. Namun dalam pemanfaatannya banyak pengguna yang belum tahu keberadaan ketiga produk tersebut. Berikut yang dikatakan oleh Vina Nuffa Jarni semester 2 mahasiswa FKIP jurusan Pendidikan Fisika "Saya ke internet biasanya akses ke yahoo atau google dan Ebook" (wawancara, 17 Mei 2017). Dalam menggunakan internet mereka lebih sering mencari informasi langsung melalui yahoo ataupun google, bukan masuk ke rumah sendiri (www.UR.ac.id). Dari beberapa mahasiswa banyak yang belum tahu tentang keberadaan fasilitas digital library, e-journal dan katalog online. Pengguna lebih banyak mencari informasi yang bersumber dari web, dalam mendukung kegiatan proses belajar dan penelitian. Lalu peneliti juga menanyakan bagaimana menurutnya tentang jaringan dan web perpustakaan dia bilang baik. Kemudian wawancara dengan Incik Zikri jurusan Hubungan International semester IV mengatakan bahwa dia sering keperpustakaan untuk buka internet, lalu dia mengatakan lumayan bisa digital, skripsi dan jurnal (wawancara 17 Mei 2017)

Pengemasan produk berbasis teknologi informasi melalui sosialisasi digital library dan e-journal prosentase pencapaian $100 \%$ dengan indikator jumlah peserta sosialisasi. Tindak lanjut dari sosialisasi ini dengan menyebarkan informasi dglib dan e-journal melalui internet dan word of mouth. Namun dalam kenyataannya jumlah pemakai media informasi ini masih kurang. (Pengguna digital library hanya 8.488 orang sementara jumlah sivitas akademika 29.554. Berdasarkan observasi diketahui bahwa hal ini disebabkan oleh kualitas konten, user interface, aliran bandwidth, dan sistem server yang belum mendukung. Di sini terlihat bahwa untuk menyediakan informasi yang lengkap maka perlu didukung dengan kemampuan kapasitas yang besar pula.Untuk itu perlu upaya dan kerjasama dengan UPT Puskom UR dalam mengupayakan perbaikan dan penyempurnaan produk-produk tersebut. Seperti yang disampaikan oleh Ibu Endang dan Ibu Evi bahwa Situs web perpustakaan di retas oleh orang yang tidak bertanggung jawab sehingga banyak ejournal yang hilang \pm 18.000 , jadi perlu kerja keras untuk mengembalikannya (wawancara 17 Maret 2017)

Pengukuran indikator pada produk katalog online adalah semua fakultas yang ada yaitu 9 fakultas sudah terintegrasi di UPT perpustakaan UR ini. Namun jurnal yang ada di fakultas tidak semua bisa terkontrol untuk menyerahkan terbitannya ke UPT pepustakaan UR ini demikian wawancara dengan Bpk. Anton Yuliarto S. Kom, bagian IT Publisher. Di mata pengguna, model pengemasan produk berbasis teknologi informasi di UPT Perpustakaan UR belum menyebar ke khalayak luas, khususnya sivitas akademika UR. Menurut salah seorang staf bagian pelayanan UR mengatakan :

UPT Perpustakaan UR dalam hal sosialisasi fasilitas layanan on-line kepada sivitas akademika amat sangat minim. Kayaknya perlu digagas personal in charge yang menangani publisitas atau semacam marketing agar pencitraan bagus, bahwa UPT Perpustakaan UR telah 
serius mengembangkan diri dengan layanan berbasis IT. (wawancara, 15 April 2017)

Hal ini senada dengan yang diungkap oleh seorang pengunjung UPT Perpustakaan UR :

Keberadaan perpustakaan saat ini tidak terlepas dari keberadaan teknologi informasi. Perlu dibentuk suatu tim untuk mempromosikan perpustakaan. Tim bisa terdiri dari tenaga TI, yang bertanggung jawab pada infrastruktur teknologi, jaringan dan aplikasi. Kemudian pustakawan, yang mempunyai kemampuan dan pengalaman untuk mengorganisasi pengetahuan. Keberadaan humas juga penting saat ini. (wawancara, 20 April 2017)

Selanjutnya, rencana yang baik harus mampu mencerminkan kebutuhan dari seluruh pengguna dan stakeholder UPT Perpustakaan UR, seperti kita ketahui bahwa keberadaan perpustakaan saat ini sangat penting untuk penunjang proses pembelajaran dapat berjalan dengan lancar serta demi terlaksananya tri dharma diperguruan tinggi.

\section{Analisis pengemasan produk Digital Library}

Luapan informasi yang terus bertambah, menuntut pengelola informasi untuk membuat kemasan informasi dan memberikan layanan informasi dengan cepat, tepat dan mudah. Untuk melaksanakan pengemasan informasi perlu didukung oleh subyek spesialis atau bekerjasama dengan tenaga ahli. Kemasan informasi yang dibuat harus selalu berkembang sesuai dengan segmen pasar yang dituju. Dengan sendirinya pengelola informasi juga harus meningkatkan pengetahuan dan kemampuan untuk mengemas informasi. Bila diukur berdasarkan penilaian kualitas jasa, maka penilaian digital library yang sudah berjalan dari tahun 2007 adalah sebagai berikut $:^{10}$

Dari sisi Keterbaruan (currency) UPT Perpustakaan UR secara periodik selalu mengupload tugas akhir mahasiswa, jadi kandungan informasi koleksi selalu bertambah dan baru. Digital library juga mudah digunakan, termasuk bagi mereka yang baru pertama kali menggunakan. (servive ability). Namun dalam hal penampilan (aesthetics and image), belum memenuhi selera pengguna demi kenyamanan. perlu ada perbaikan baik dari interface, desain, warna, kalau perlu ada visualisasi agar nampak menarik. Dalam hal keselarasan (conformance) masih memakai standar lokal.

Tingkat Kebergunaan (usability) nilai ditentukan oleh pengguna sesuai persepsi subyektif berdasarkan pengalaman mereka. Digital library UPT Perpustakaan UR dari sisi kualitas konten saat ini belum menjawab kebutuhan pengguna, hal ini bisa dilahat dari segi :

(a) Efektivitas sistem, seberapa jauh perpustakaan digital mampu secara tepat memberikan solusi informasi bagi pengguna, termasuk di sini adalah relevansi informasi yang ada dengan kebutuhan pengguna. Saat ini kemasan informasi berupa digital library yang dimiliki oleh UPT Perpustakaan UR masih sangat sederhana sekali, yang

\footnotetext{
${ }^{10}$ Putu Laxman Pendit. Perpustakaan Digital : Perspektif perpustakaan Perguruan Tinggi Indonesia.

Jakarta : Sagung Seto, 2007. hal. 282-283
} 
ditampilkan hanyalah abstraknya saja. Alasan mengapa UPT Perpustakaan UR belummenerapkan digital library $100 \%$ fultext berkisar tentang kerahasiaan, plagiat, hak cipta dan infrastruktur informasi yang belum memadai.

(b) Efisiensi sistem yaitu kemampuan sistem menghemat waktu dan upaya pengguna dalam mendapatkan informasi dari berbagai sumber. Juga disediakan penelusuran lain ke katalog online UPT Perpustakaan UR, dan e-journal yang dikelola oleh UPT perpustakaan UR. Di sini tersedia hanya dari lingkungan lokal.

(c) Kepuasan yaitu ukuran subyektif tentang kemudahan pemakaian, tampilan, struktur informasi, kandungan, keluasan jaringan (seberapa banyak sumber yang bisa dihubungi).

Dari pendapat beberapa informan di atas, tingkat kepuasan pemakai digital library UPT perpustakaan belum bisa dikatakan memuaskan. Masih perlu pengembangan dari berbagai sisi (tampilan, kebijakan download, keragaman content).

\section{Analisis Pengemasan Produk E-Journal}

Targeting pemanfaatan informasi melalui e-journal adalah dosen di lingkungan UR. Keberadaan e-journal tetap disambut dengan baik dan memiliki pelanggan loyal, walaupun kualitas informasi yang tersedia tidak memenuhi harapan seluruh pengguna. Kandungan informasi apapun itu kualitasnya tetap bisa diolah sebagai tambahan referensi bagi pengguna. Berdasarkan deskripsi di atas model pengemasan produk e-journal sebaiknya dijalankan melalui sosialisasi, yaitu dengan mendatangkan pihak vendor sebagai narasumber dalam penelusuran informasi melalui e-journal ini. Karena beberapa dosen belum banyak yang tahu bagaimana cara melakukan penelusuran, agar mendapatkan informasi yang dibutuhkan (misalnya membedakan abstrak, review, fultext, dan lain-lain). Dari pihak UPT Perpustakaan UR juga perlu menanyakan kedalaman informasi yang dibutuhkan untuk membuat evaluasi (misalnya apakah tersedia layanan untuk mengetahui artikel apa yang sering diakses, berapa kali artikel tersebut di hit oleh user, kapan penelusuran dilakukan, dari IP mana yang sering akses, dan lain-lain).

Diharapkan dengan sosialisasi ini pengguna tidak akan kecewa karena dari awal sudah diinformasikan bahwa ada alternatif jenis penelusuran yang memang cuma abtsrak, review, dan brief article di dalamnya. Perlu ada perubahan informasi pada label e-journal, yang menyebutkan bahwa UPT Perpustakaan melanggan $e$ journal dari berbagai disiplin ilmu dalam bentuk fultext.

Informasi label (dalam kemasan melalui situs) ini dapat menyesatkan bagi pengguna dengan memberikan informasi yang berlebihan; atau dengan tidak etis menyebutkan bahwa produk mengandung atribut lebih dari yang diinginkan. ${ }^{11}$

Dalam hal kualitas konten dari e-journal, diakui oleh penulis bahwa konten kurang mendalam dengan kata lain informasi yang didapat belum sesuai dengan harapan pengguna.Selama ini konten e-journal diseleksi oleh petugas perpustakaan (pustakawan),padahal pustakawan belum memahami benar secara spesifik informasi apa saja yang dibutuhkan oleh pengguna. Akan lebih efektif apabila sebelum mengambil langkah untuk berlangganan e-journal, UPT Perpustakaan UR

\footnotetext{
${ }^{11}$ Terence A Shimp. Periklanan Promosi, jilid 1 : Aspek Tambahan Komunikasi Pemasaran Terpadu.Jakarta : Erlangga, 2003. hal. 103
} 
perlu mengkoordinasikan terlebih dahulu dengan beberapa dosen aktual untuk membantu memilih artikel-artikel jurnal elektronik yang sesuai dengan bidang ilmu yang dikaji (dosen sebagai mitra perpustakaan) walaupun ini sudah pernah dilakukan sebelumnya demikian penjelasan bu evi salah seorang kabag IT diperpustakaan UR, tetapi ada baiknya dilakukan survey ulang agar ejournal yang dilanggan benar-benar sesuai dengan kebutuhan pengguna saat ini. Sehingga, sumber informasi yang terdapat di e-journal berdasarkan kajian kebutuhan pengguna. Jadi decision maker di sini adalah pengguna (dosen), UPT Perpustakaan UR berperan sebagai fasilitator dan akomodator. Dengan kata lain di sini perlu subject specialist, sehingga idealnya pustakawan berasal dari berbagai disiplin ilmu. Semakin spesialis seorang pustakawan, maka layanan yang diberikan akan terasa kedalamannya. ${ }^{12}$

Faktor budaya juga menyebabkan lesunya sivitas akademika dalam meng akses e-journal, kebanyakan dosen masih memprioritaskan jurnal tercetak dari pada jurnal elektronik. Alasannya karena jurnal tercetak disarikan dan disebarluaskan ke kalangan ilmiah, sedangkan jurnal elektronik tidak disebarkan kepada dosen secara langsung. Apalagi ditambah idiom seseorang yang mempercayai bahwa jurnal yang tercetak pada media kertas lebih awet daripada yang tersimpan pada media elektronik yang sangat tergantung pada mesin pembaca. Selain itu ada beberapa permasalahan dalam akses e-journal dilingkungan UR, yaitu : ${ }^{13}$

1. Kurangnya penguasaan bahasa Inggris.

Kita sadari bahwa tidak semua mahasiswa dan dosen UR menguasai bahasa Inggris, tetapi sebagian besar informasi di Internet tersedia dalam bahasa Inggris. Maka penguasaan bahasa Inggris akan menjadi salah satu keunggulan (advantage).

2.. Kurangnya sumber informasi dalam bahasa Indonesia.

Untuk itu sumber informasi dalam bahasa Indonesia harus tersedia. Saat ini belum banyak sumber informasi pendidikan yang tersedia dalam bahasa Indonesia. Konsep berbagi (sharing), misalnya dengan membuat materi- materi pendidikan di internet, belum merasuk. Untuk itu langkah ke depan dalam membuat $e$-journal adalah langkah tepat dalam penyebaran informasi terseleksi baik dalam bahasa Indonesia maupun bahasa Inggris.

\section{Analisis Pengemasan Produk Katalog Online}

Katalog Online atau yang disebut dengan menggunakan Slim Akasia, sebagai awal dari terintegrasinya koleksi yang ada di perpustakaan-perpustakaan di lingkungan UR, merupakan salah satu kemajuan di bidang penelusuran informasi online. Dengan adanya katalog online ini pengguna, siapapun bisa mengakses koleksi apa saja yang dimiliki oleh UPT Perpustakaan UR dan perpustakaan-perpustakaan di lingkungan UR. Namun sejauh ini baru bisa memberikan layanan katalog atau penelusuran informasi secara online, belum sampai pada tahap pemesanan buku dan perpanjangan buku secara online. Katalog

\footnotetext{
${ }^{12}$ Kardi. "Revitalisasi Peran Pustakawan dalam Implementasi Knowledge Management." Visipustaka.9 (2) Agustus 2007. hal. 10-16

${ }^{13}$ Budi Rahardjo. "Internet Untuk Pendidikan". 20 Juni 2008 <http://budi.insan.co.id/articles/internet- pendidikan.doc >
} 
online merupakan media informasi dan komunikasi bagi pustakawan dan pengguna. Pengguna bisa secara online mengusulkan buku yang diperlukan dan memberikan saran dan kritik melalui media ini.

\section{SIMPULAN}

Berdasarkan pembahasan diatas dapat disimpulkan bahwa :

1. UPT Perpustakaan UR sudah mengemas produk berbasis teknologi informasi ( Digital library, E-jurnal, Katalog online) dengan baik, dari hasil analisis diperoleh tingkat penggunaan dan pemanfaatan informasi tersebut masih rendah karena dari 29.554 sivitas akademika hanya 8.488 yang menjadi anggota perpustakaan jika dipresentasikan hanya $29 \%$ dan 1.815 penggunaan e-jurnal di tahun 2017, kemudian untuk katalog online belum melayani pemesanan dan perpanjangan secara online

2. Persepsi stakeholder terhadap layanan berbasis teknologi informasi sudah baik namun masih perlu pembenahan dari segi keamanan, dimana pernah kejadian bahwa situs web Perpustakaan UR diretas oleh orang yang tidak bertanggung jawab.

\section{DAFTAR PUSTAKA}

“AfricanDigital Library Glossary". (2002).20 Juni 2008 <http://www.africandl. org.za/glossary.htm>

Alma, Buchari. 1998.Manajemen Pemasaran dan Pemasaran Jasa. Bandung:Alfabeta,

Badollahi Mustafa.1996. Promosi Jasa perpustakaan. Jakarta: Universitas Terbuka,

Fandy Tjiptono. 2008.Pemasaran Strategik. Yogyakarta: Andi,. hal. 5 . 1995.Strategi Pemasaran Yogyakarta : andi Offset, Hal.200

Joko Santoso. "Kemas Ulang Informasi Elektronis Sebagai Langkah Inovatif Layanan Perpustakaan

Lasa Hs. 2005. Manajemen Perpustakaan. Yogyakarta : Gama Media,

Moleong, Lexy J. 2004. Metodologi Penelitian Kualitatif. Bandung: Rosda.

Mustafa, Badollahi. Promosi Jasa perpustakaan. Jakarta: Universitas Terbuka,

Teknologi Informasi dan Pengaruhnya Pada Pengemasan Informasi.” 25 Maret $2008<w w w . p n r i . g o . i d>$

"Perpustakaan Digital" 20 juni 2008 <http://encyclopaedia.thefreedictionary.com/digital+library>

PR Smith. 1998. Marketing Communications: An Integrated Approach. London: Kogan Page, P. 7

Yuhelmi, Yuhelmi. "PROMOSI PERPUSTAKAAN DI UNIT PELAKSANA TEKNIS (UPT) PERPUSTAKAAN UNIVERSITAS LANCANG KUNING.” INA-Rxiv, 25 July 2018. Web. 